\title{
A vegan regimen with reduced medication in the treatment of hypertension
}

\author{
By OLOV LINDAHL, LARS LINDWALL, ALF SPÅNGERG, ̊KE \\ STENRAM AND PER ARNE ÖCKERMAN \\ Department of Orthopaedic Surgery, University Hospital (Regionsjukhuset), Linköping, \\ S-581 85 Linköping, Sweden
}

\section{(Received 5 October 1983 - Accepted 19 January 1984)}

\begin{abstract}
1. Twenty-nine patients who had suffered from essential hypertension for an average of 8 years, all receiving long-term medication for hypertension, were subject to therapy with vegan food for 1 year. In almost all cases medication was withdrawn or drastically reduced. There was a significant decrease in systolic and diastolic blood pressure. A number of reported symptoms disappeared.

2. There was a significant improvement in a number of clinical variables as well as a significant change in various biochemical indices such as urea, haptoglobin, cholesterol and triglyceride concentrations in blood.

3. Subjectively all patients reported improvement.

4. Selected patients, with a fear of side-effects of medication, who are interested in alternative health care might replace conventional medication with this dietary regimen.
\end{abstract}

The term essential hypertension implies that the aetiology of this disease is unknown. Notwithstanding this, there are a number of hypotheses about the origin of high blood pressure. Of these, the theory that increased intake of salt can, in certain sensitive individuals, be a plausible explanation has aroused some interest in recent years (Freis, 1976; Haddy, 1980). Obesity is also considered to be of importance (Chiang et al. 1969; Mann, 1974). However, these hypotheses have not become well accepted, so therapy consisting only of weight reduction and low salt intake is not normal practice. Medical advice to the public recommends antihypertensive medication and patients are told to continue with their medication for the rest of their lives.

In Sweden there is an active health movement which claims that a radically altered diet, such as a vegan diet, can improve or cure a number of diseases, including hypertension. Indeed in the medical literature there is information which supports the concept of dietary therapy (Black, 1979).

In order to assess the possible effect of a vegan diet on hypertension, we have followed a series of patients who were treated with a vegan regimen for 1 year.

\section{EXPERIMENT AL}

\section{Subjects}

Twenty-nine patients with long-established, hospital-verified hypertension were admitted to a health centre for two $12 \mathrm{~d}$ periods 4 months apart, and again after 1 year. The following were the criteria for participation in the study: (1)'age 25-70 years, (2) willingness to change completely to a vegan regimen, without milk or eggs, for 1 year and ability to finance the care and necessary travel, (3) a disease duration of at least 1 year with unchanged or perhaps even worsened symptoms, (4) existence of verified hypertension. The composition of the sample with regard to sex and age is shown in Table 1.

It can be said, of course, that this is a selected group not representative of Swedish hypertensive patients in general. This is to some extent true for most hypertensive-patient groups that are used for the testing of different therapies. However, in the patient group 


\section{Table 1. Age and sex distribution of hypertensive patients who underwent vegan diet therapy}

\begin{tabular}{llccccc}
\hline \hline Age (years) $\ldots$ & $<40$ & $40-49$ & $50-59$ & $60-69$ & Total \\
\hline Men & 0 & 3 & 6 & 1 & 10 \\
Women & 2 & 5 & 10 & 2 & 19 \\
Total & 2 & 8 & 16 & 3 & 29 \\
\hline
\end{tabular}

studied here, there was a further selection in that the patients were especially motivated to undertake individual initiatives in order to improve their health, they were more than usually dissatisfied with earlier treatment and they had sufficient financial resources to pay for the therapy, which was not subsidized by the government.

The duration of the disease was on average 8.2 years (range 1-26 years). The maximal registered blood pressure according to earlier case records (usually at the primary diagnosis and the introduction of the drug therapy) was on average $198 / 115 \mathrm{mmHg}$, with a range for systolic pressure of $150-260 \mathrm{mmHg}$ and for diastolic pressure $95-160 \mathrm{mmHg}$. The main diagnosis of hypertonia essentialis was in all cases made by doctors other than the authors; in twenty-four cases in hospitals, and in five cases by specialists outside the hospitals.

All patients were taking antihypertensive medicines, using on average 2.6 medicines each (range 1-8). In addition, there were numerous medications for concurrent diseases, for example rheumatic ailments, migraine and ulcerative colitis.

At the beginning of the diet therapy, eight patients had, in spite of their medication, a blood pressure which exceeded $165 / 95 \mathrm{mmHg}$. In a majority of the patients, blood pressure was within the normal range (Fig. 1). Despite this, they were not at all satisfied with their condition, and as well as the common fear of lifelong medication with the risk of side-effects, the patients also had a number of disturbing symptoms which they ascribed either to their medicine or to the underlying disease (Table 2).

\section{Methods}

The food the patients received at the health centre, and which they were recommended to use as much as possible in their homes, was vegan food without any animal food such as meat, fish or eggs and also without milk products. Drinking water was spring water and not chlorinated tap water. Coffee, Indian or China tea, chocolate, sugar and salt were excluded while certain spices, especially herbal spices were allowed, with large individual variations. Water or herbal teas to an amount of 1.5 litres every $24 \mathrm{~h}$ was recommended. The vegetables used were preferably eaten in a fresh and raw condition and were grown without the use of insecticides. Vegetarian cooked dishes, especially soups, were included in the food, but were not predominant with respect to raw vegetables. The diet was analysed for its nutrient content, which included vitamins and certain mineral substances (Abdulla et al. 1981) and contained all nutrients in amounts recommended by the US Food and Drug Administration. With respect to minerals, trace elements and vitamins, the content was usually greater than that recommended. Vitamins $D$ and $B_{12}$ were the only exceptions, and in these cases a supplement was considered although it was decided that it would not be given.

During their stay at the health centre, patients were given lessons and practical training in the recommended method of food preparation. They were also given lectures on the composition of the diet. On the first visit to the health centre the patients were subjected to a regimen of fruit juice only, usually for $7 \mathrm{~d}$. During the period of treatment they were also given a number of herbal preparations and were encouraged to use them at home. 


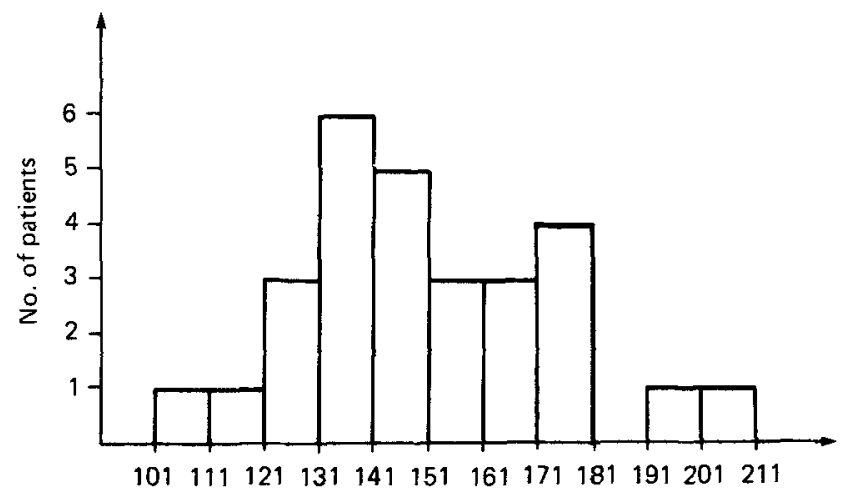

Systolic blood pressure $(\mathrm{mmHg})$

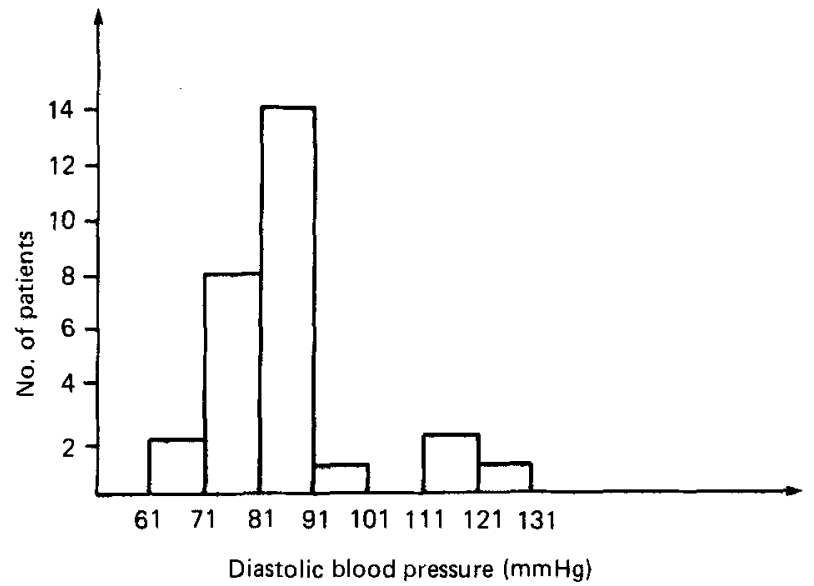

Fig. 1. Blood pressure on conventional medication before the start of vegan food therapy in the treatment of hypertensive patients $(n 28)$.

Table 2. Subjective symptoms at the commencement of the vegan diet therapy

Headache*
Dizziness*
Tiredness, often expressed*
Feeling of pressure over temple, eyes, in the head
Throbbing in the head
Spontaneous attacks of headache
Fainting
Nervousness
Anxiety
Forgetfulness
Difficulties in concentrating
Worsened sight
or other affections of the sight

Breathlessness

Chest pain

Irregular heart rhythm

Heart beating (rapid)

Bad condition

Urinating at night

Sweating

Indisposition in connection

with medication

Urticaria because of the medicine

Itching because of the medicine

* Most common symptoms. 
The patients were recommended to spend as much time as possible in the fresh air and preferably to undertake daily some kind of physical activity, such as walking. However, they were not encouraged to undertake regular fitness training. With the exception of a few essential medicines (for example, insulin) patients were encouraged to give up medicines when they felt that these were no longer needed. Thus, analgesics were dispensed with in the absence of pain, tranquillizers when anxiety was not experienced and sleep was sound, and antihypertensive medication when the blood pressure was normal.

Psychotherapy or attempts to solve any personal problems or conflicts the patients might have were not attempted. There were, however, discussions about their disease and their anxiety concerning various troublesome symptoms as well as side-effects of their medicine. They were also encouraged to believe that they would eventually become symptom-free or 'healthy', provided they followed the regimen strictly.

\section{Statistical methods}

For a number of clinical variables (for example, resting pulse rate and blood pressure) and for a number of laboratory tests, the initial values were compared with the corresponding values at 4 and 12 months. Student's $t$ test was used to estimate the statistical significance of differences. For analysis of the relation between subjective improvement and compliance, variance analysis was used.

In order to evaluate the patients' subjective symptoms the so-called longitudinal superiority test (Lindahl \& Lindwall, 1978) was used, in which the patients recorded their general apprehension concerning their health on a scale from 0 to $4(0$, subjectively symptom-free; 4 , very severe symptoms). This recording was done at weekly intervals for up to 6 months before the introduction of the treatment. The time of entry to the study (the initial admission) was randomized, which made it possible to estimate whether the change of symptoms which occurred during the treatment differed significantly from the 'spontaneous' variations of the disease, which existed during the control period before treatment.

\section{Clinical examinations}

The patients' case records were obtained from their previous doctors and hospitals. A routine case history and clinical examination was performed in order to verify the diagnosis and for a general assessment of the patients' condition. The intake of medicine was noted.

The following clinical investigations were performed: systolic and diastolic blood pressure was measured supine with a $\mathrm{Hg}$ manometer after $15 \mathrm{~min}$ bed rest. Resting pulse rate was measured after $15 \mathrm{~min}$ bed rest. Body-weight and length were recorded. Visual acuity was assessed with normal glasses using a standard chart and without correction, other than the patients' own glasses. Physical fitness was measured using the Monark bicycle ergometer. The index used for comparison was the pulse level after 6 min cycling at the same load.

\section{Laboratory investigations}

Analysis of blood and urine were performed at the Department of Clinical Chemistry in Lund. The measurements were made before treatment, after 4 months and after 1 year.

\section{Further examinations}

At the 1-year follow-up the patients were asked to what extent they had followed the regimen. Our assessment of a compliance of between 25 and $100 \%$ was, of course, a subjective estimate.

The patients' sick-leave the year before therapy and during therapy was recorded in order 
Table 3. Subjective results after 4 months and after 1 year of vegan diet therapy in hypertensive patients (n 26)

\begin{tabular}{lcccccc}
\hline \hline & $\begin{array}{c}\text { Completely } \\
\text { recovered }\end{array}$ & $\begin{array}{c}\text { Much } \\
\text { better }\end{array}$ & Better & Unchanged & Worse \\
\hline & 7 & 13 & 6 & 0 & 0 \\
& 8 & 14 & 4 & 0 & 0 \\
\hline
\end{tabular}

Table 4. Comparison of symptoms before and after 1 year of vegan diet therapy in hypertensive patients (n 26)

\begin{tabular}{ccccccc}
\hline \hline & \multicolumn{6}{c}{ No. of symptoms* } \\
\cline { 2 - 6 } & Before & After & Before & After & Before & After \\
\hline 5 & 0 & 3 & 0 & 4 & 0 \\
3 & $1 \dagger$ & 2 & 0 & 4 & 0 \\
5 & $2 \dagger$ & 4 & 0 & 2 & 0 \\
4 & 0 & 4 & 0 & 4 & 0 \\
4 & 0 & 3 & 0 & 4 & 0 \\
3 & 0 & 5 & $1 \dagger$ & 4 & 0 \\
6 & $2 \dagger$ & 4 & 0 & 3 & 0 \\
2 & 0 & 4 & 0 & 4 & 0 \\
4 & 0 & 2 & 0 & & \\
\hline \hline
\end{tabular}

* Total before, 96; after, 6 .

$\dagger$ Symptoms less pronounced.

to obtain some idea of the financial consequences of the patients' sickness. The same comparison was made for their medication, in that the cost of medicines for the 2 years was calculated with the aid of the official price-list of the Swedish pharmacies for the year in question (without taking into consideration the state subsidy on pharmaceuticals).

\section{RESULTS}

Drop-outs. Three of the patients did not continue their diet beyond 1-2 months. One had practical difficulties in adhering to the regimen as the nearest health-food shop was $30 \mathrm{~km}$ away. Two discontinued the diet on medical advice.

Subjective variables. A significant improvement was detected after the treatment, with the aid of the longitudinal superiority test for subjective symptoms that had been estimated on a $0-4$ scale (from none to very severe). The values for the 20 weeks preceding the start of the regimen were compared with those during the 2 nd and 21 st weeks of treatment (4 months). On both occasions the difference was highly significant $(P<0.001)$ at 1.18 and 1.22 scale units respectively.

The result of subjective evaluation of the patients was improvement of, or freedom from, symptoms in all cases after 4 months as well as after 1 year (Table 3).

The number of symptoms of which the patients complained at the beginning of the treatment was on average 3.7. After 1 year, twenty-two of the twenty-six patients claimed to have no adverse symptom. In four cases, one or two symptoms remained but were less pronounced (Table 4).

Objective variables. The clinical variables examined at the 4-month and 1-year follow-up 
Table 5. Clinical variables before and after 1 year of vegan diet therapy in hypertensive patients ( $\mathrm{n} 26$ )

(Mean values and standard deviations)

\begin{tabular}{|c|c|c|c|c|c|c|}
\hline & \multirow{2}{*}{$\begin{array}{l}\text { Period of } \\
\text { therapy } \\
\text { (months) }\end{array}$} & \multicolumn{2}{|c|}{ Before therapy } & \multicolumn{2}{|c|}{ After therapy } & \multirow{2}{*}{$\begin{array}{c}\text { Statistical } \\
\text { significance } \\
\text { of the difference }\end{array}$} \\
\hline & & Mean & SD & Mean & SD & \\
\hline \multirow[t]{2}{*}{ Body-wt (kg) } & $0-4$ & $78 \cdot 2$ & $15 \cdot 3$ & 68.0 & $14 \cdot 0$ & $* * *$ \\
\hline & $0-12$ & $78 \cdot 2$ & $15 \cdot 3$ & $70 \cdot 4$ & $14 \cdot 3$ & $* * *$ \\
\hline \multirow{2}{*}{$\begin{array}{l}\text { Physical work } \\
{\text { (beats } / \mathrm{min})^{\dagger}}^{\dagger}\end{array}$} & $0-4$ & 140 & 15.0 & 125 & $15 \cdot 2$ & $* * *$ \\
\hline & $0-12$ & 140 & $15 \cdot 0$ & 124 & $18 \cdot 0$ & $* * *$ \\
\hline \multirow{2}{*}{$\begin{array}{l}\text { Pulse at rest } \\
\text { (beats } / \mathrm{min} \text { ) }\end{array}$} & $0-4$ & 71 & $9 \cdot 3$ & 65 & $9 \cdot 2$ & $*$ \\
\hline & $0-12$ & 71 & $9 \cdot 3$ & 67 & $7 \cdot 8$ & NS \\
\hline \multirow{2}{*}{$\begin{array}{l}\text { Systolic blood } \\
\text { pressure (mmHg) }\end{array}$} & $0-4$ & 151 & $25 \cdot 7$ & 144 & $19 \cdot 1$ & $*$ \\
\hline & $0-12$ & 151 & $25 \cdot 7$ & 142 & $20 \cdot 4$ & $* *$ \\
\hline \multirow{2}{*}{$\begin{array}{l}\text { Diastolic blood } \\
\text { pressure }(\mathrm{mmHg})\end{array}$} & $0-4$ & 88 & 14.9 & 78 & $7 \cdot 1$ & $* *$ \\
\hline & $0-12$ & 88 & 14.9 & 83 & $9 \cdot 6$ & $\bullet$ \\
\hline
\end{tabular}

NS, not significant; *P<0.05; ** $P<0.01$, *** $P<0.001$.

$\dagger 6$ min cycling (constant load) using the Monark bicycle ergometer.

are shown in Table 5. After 1 year there was a significant decrease in blood pressure, pulse rate after a standard work load and body-weight. The decrease in the resting pulse was significant only at the 4-month follow-up. Visual acuity showed a non-significant improvement but in many cases could not be judged with certainty as the technique of investigation had not been satisfactorily standardized.

When the decrease in blood pressure was considered for the entire group it was found that it occurred at the time when most of the medicines were withdrawn. Of the twenty-six patients, twenty had given up their medication completely after 1 year while six still took some medicine although the dose was lower, usually halved. The remaining medicines were usually 'beta-blockers'. The moderate reduction in the average blood pressure must be considered in relation to the fact that many patients had low (perhaps too low; for example $105 / 85 \mathrm{mmHg}$ ) blood pressure at the start of the regimen and afterwards had blood pressures that were higher but still within normal limits.

The systolic blood pressure at the l-year follow-up was unchanged in four cases, higher in four cases and lower in eighteen. In two of the four cases where blood pressure increased after commencing the regimen without medication, the values were 175 and $190 \mathrm{mmHg}$ (a rise of 5 and $10 \mathrm{mmHg}$ respectively) but for the rest of the cases the values were still below the normal limit of $165 \mathrm{mmHg}$. The diastolic blood pressure was unchanged after 1 year in three cases, higher but not above $95 \mathrm{mmHg}$ in eight cases and lower in fifteen cases.

At the beginning of the treatment only eight patients had a blood pressure over $165 / 95 \mathrm{mmHg}$. In one such case (blood pressure $180 / 85 \mathrm{mmHg}$ ) the treatment was discontinued. In all cases, where despite medication blood pressure was elevated before treatment, the systolic blood pressure decreased by an average of $10 \mathrm{mmHg}$ and the diastolic by $13 \mathrm{mmHg}$ (see Fig. 2).

The biochemical indices are summarized in Tables 6-10.

Many of these variables showed significant changes. The blood electrolyte concentrations were clearly altered as were erythrocyte sedimentation rate, haptoglobin and urea. Of particular interest was the reduction in triglycerides and cholesterol. There was no significant change in haemoglobin, erythrocyte counts or packed cell volume after 4 or 12 months. The $24 \mathrm{~h}$ excretion of chlorides in the urine was found to be reduced at the 4-month follow-up but not at 12 months. The $\mathrm{pH}$ of the urine did not change significantly. 


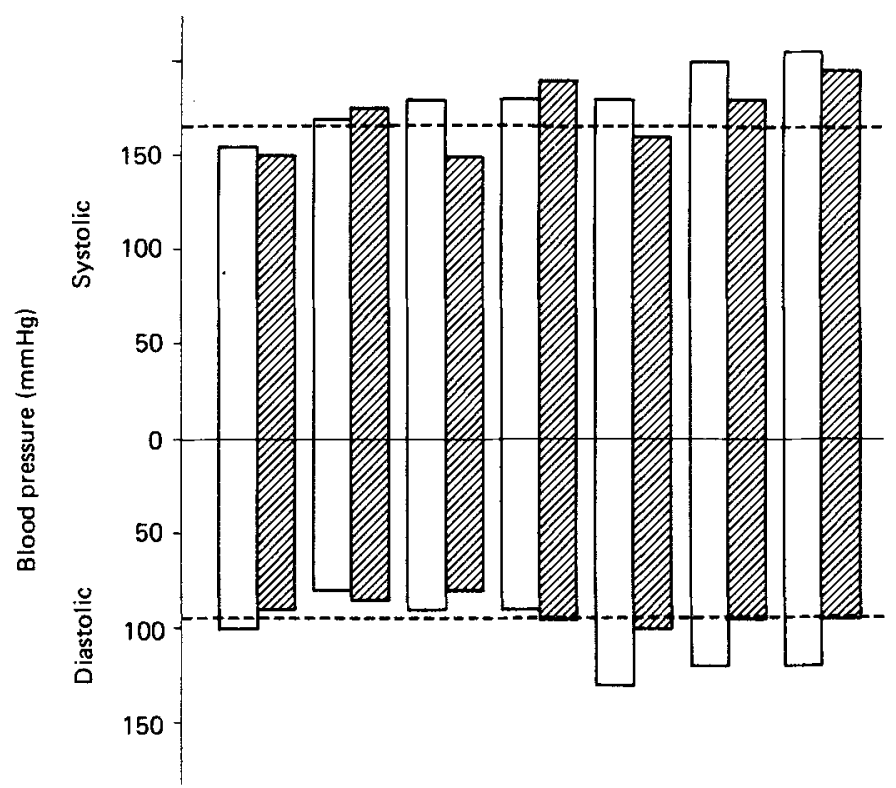

Fig. 2. Comparison of blood pressure before vegan food therapy and after 1 year of treatment in patients (n 7) who, despite conventional medication, had high blood pressure ( $>165 / 95 \mathrm{mmHg}$ ) at the start of food therapy. (-----), Limits for normal blood pressure $(165 / 95 \mathrm{mmHg}) .(\square)$, Before treatment; (1), after treatment.

Table 6. Serum electrolytes (mmol/l) before and after 1 year of vegan diet therapy in hypertensive patients (n 26)

(Mean values and standard deviations)

\begin{tabular}{|c|c|c|c|c|c|c|}
\hline \multirow{2}{*}{$\begin{array}{c}\text { Serum } \\
\text { electrolytes }\end{array}$} & \multirow{2}{*}{$\begin{array}{c}\text { Period of } \\
\text { therapy (months) }\end{array}$} & \multicolumn{2}{|c|}{ Before therapy } & \multicolumn{2}{|c|}{ After therapy } & \multirow{2}{*}{$\begin{array}{c}\text { Statistical } \\
\text { significance } \\
\text { of the difference }\end{array}$} \\
\hline & & Mean & SD & Mean & SD & \\
\hline Sodium & $\begin{array}{l}0-4 \\
0-12\end{array}$ & $\begin{array}{l}144 \cdot 0 \\
144 \cdot 0\end{array}$ & $\begin{array}{l}3 \cdot 8 \\
3 \cdot 9\end{array}$ & $\begin{array}{l}148 \cdot 5 \\
141 \cdot 4\end{array}$ & $\begin{array}{l}3 \cdot 3 \\
2 \cdot 1\end{array}$ & $* * *$ \\
\hline Potassium & $\begin{array}{l}0-4 \\
0-12\end{array}$ & $\begin{array}{l}4 \cdot 28 \\
4 \cdot 30\end{array}$ & $\begin{array}{l}0 \cdot 5 \\
0 \cdot 5\end{array}$ & $\begin{array}{l}4 \cdot 58 \\
4 \cdot 12\end{array}$ & $\begin{array}{l}0 \cdot 4 \\
0 \cdot 3\end{array}$ & NS \\
\hline Calcium & $\begin{array}{l}0-4 \\
0-12\end{array}$ & $\begin{array}{l}2 \cdot 45 \\
2 \cdot 45\end{array}$ & $\begin{array}{l}0 \cdot 2 \\
0 \cdot 2\end{array}$ & $\begin{array}{l}2 \cdot 63 \\
2 \cdot 43\end{array}$ & $\begin{array}{l}0 \cdot 2 \\
0 \cdot 1\end{array}$ & NS \\
\hline Phosphate & $\begin{array}{l}0-4 \\
0-12\end{array}$ & $\begin{array}{l}0.81 \\
0.83\end{array}$ & $\begin{array}{l}0 \cdot 2 \\
0 \cdot 2\end{array}$ & $\begin{array}{l}1.06 \\
1.02\end{array}$ & $\begin{array}{l}0 \cdot 2 \\
0 \cdot 2\end{array}$ & $\begin{array}{l}* * * \\
* * *\end{array}$ \\
\hline
\end{tabular}

NS, not significant; ${ }^{* *} P<0.01,{ }^{* * *} P<0.001$.

The patients' self-assessment of their compliance with the diet was on average $84 \%$ (Fig. 3 ). The correlation between the extent of subjective improvement and compliance to the diet was highly significant $(P<0.001)$.

The cost of the hospital care during the year before the stay at the health centre was 267750 SEK (11.1 SEK $\sim £ 1$ sterling) $(n 26)$ and for the year after, 31500 SEK, a saving of 9087 SEK/patient during the year. The corresponding values for medicines were 925 and 96 SEK, which was equivalent to a cost-saving of $829 \mathrm{SEK} /$ patient during the year. 
Table 7. Serum metabolites before and after 1 year of vegan diet therapy in hypertensive patients (n 26)

(Mean values and standard deviations)

\begin{tabular}{|c|c|c|c|c|c|c|}
\hline \multirow{2}{*}{$\begin{array}{c}\text { Serum } \\
\text { metabolites }\end{array}$} & \multirow{2}{*}{$\begin{array}{c}\text { Period of } \\
\text { therapy (months) }\end{array}$} & \multicolumn{2}{|c|}{ Before therapy } & \multicolumn{2}{|c|}{ After therapy } & \multirow{2}{*}{$\begin{array}{c}\text { Statistical } \\
\text { significance } \\
\text { of the difference }\end{array}$} \\
\hline & & Mean & SD & Mean & SD & \\
\hline $\begin{array}{l}\text { Urate } \\
(\mu \mathrm{mol} / \mathrm{l})\end{array}$ & $\begin{array}{l}0-4 \\
0-12\end{array}$ & $\begin{array}{l}354 \\
353\end{array}$ & $\begin{array}{l}90.5 \\
91.9\end{array}$ & $\begin{array}{l}489 \\
344\end{array}$ & $\begin{array}{r}131 \cdot 8 \\
70 \cdot 2\end{array}$ & $\begin{array}{l}* * * \\
\text { NS }\end{array}$ \\
\hline $\begin{array}{l}\text { Bilirubin } \\
(\mu \mathrm{mol} / \mathrm{l})\end{array}$ & $\begin{array}{l}0-4 \\
0-12\end{array}$ & $\begin{array}{l}14.9 \\
14.8\end{array}$ & $\begin{array}{l}5 \cdot 2 \\
5 \cdot 2\end{array}$ & $\begin{array}{r}14 \cdot 2 \\
8 \cdot 7\end{array}$ & $\begin{array}{l}7 \cdot 2 \\
3 \cdot 7\end{array}$ & $\begin{array}{l}\text { NS } \\
* * *\end{array}$ \\
\hline $\begin{array}{l}\text { Cholesterol } \\
(\mathrm{mmol} / 1)\end{array}$ & $\begin{array}{l}0-4 \\
0-12\end{array}$ & $\begin{array}{l}6 \cdot 75 \\
6 \cdot 77\end{array}$ & $\begin{array}{l}1 \cdot 0 \\
1 \cdot 1\end{array}$ & $\begin{array}{l}5 \cdot 63 \\
5 \cdot 80\end{array}$ & $\begin{array}{l}1.4 \\
1.2\end{array}$ & $\begin{array}{l}* * * \\
* * *\end{array}$ \\
\hline $\begin{array}{l}\text { Triglycerides } \\
(\mathrm{mmol} / \mathrm{l})\end{array}$ & $\begin{array}{l}0-4 \\
0-12\end{array}$ & $\begin{array}{l}1 \cdot 42 \\
1 \cdot 38\end{array}$ & $\begin{array}{l}0.7 \\
0.7\end{array}$ & $\begin{array}{l}1.04 \\
1.29\end{array}$ & $\begin{array}{l}0.4 \\
0.6\end{array}$ & $\begin{array}{l}* * \\
\text { NS }\end{array}$ \\
\hline $\begin{array}{l}\text { Urea } \\
\text { (mmol/l) }\end{array}$ & $\begin{array}{l}0-4 \\
0-12\end{array}$ & $\begin{array}{l}5 \cdot 15 \\
5 \cdot 15\end{array}$ & $\begin{array}{l}1.6 \\
1.7\end{array}$ & $\begin{array}{l}2.63 \\
3.52\end{array}$ & $\begin{array}{l}1.3 \\
0.9\end{array}$ & $* * *$ \\
\hline
\end{tabular}

NS, not significant, ${ }^{* *} P<0.01,{ }^{* * *} P<0 \cdot 001$.

Table 8. Blood proteins before and after 1 year of vegan diet therapy in hypertensive patients

(Mean values and standard deviations)

\begin{tabular}{|c|c|c|c|c|c|c|}
\hline & \multirow{2}{*}{$\begin{array}{l}\text { Period of } \\
\text { therapy (months) }\end{array}$} & \multicolumn{2}{|c|}{ Before therapy } & \multicolumn{2}{|c|}{ After therapy } & \multirow{2}{*}{$\begin{array}{c}\text { Statistical } \\
\text { significance } \\
\text { of the difference }\end{array}$} \\
\hline & & Mean & SD & Mean & SD & \\
\hline $\begin{array}{l}\text { Albumin } \\
(\mathrm{g} / \mathrm{l})\end{array}$ & $\begin{array}{l}0-4 \\
0-12\end{array}$ & $\begin{array}{l}43 \cdot 2 \\
43 \cdot 5\end{array}$ & $\begin{array}{l}4 \cdot 6 \\
4 \cdot 5\end{array}$ & $\begin{array}{l}44 \cdot 5 \\
37 \cdot 7\end{array}$ & $\begin{array}{l}3 \cdot 3 \\
4 \cdot 1\end{array}$ & $\underset{* * *}{\text { NS }}$ \\
\hline $\begin{array}{l}\text { Haptoglobin } \\
(\mathrm{g} / \mathrm{l})\end{array}$ & $\begin{array}{l}0-4 \\
0-12\end{array}$ & $\begin{array}{l}1.39 \\
1.31\end{array}$ & $\begin{array}{l}0 \cdot 6 \\
0.5\end{array}$ & $\begin{array}{l}0 \cdot 96 \\
1 \cdot 10\end{array}$ & $\begin{array}{l}0.6 \\
0.5\end{array}$ & $\begin{array}{c}* * * \\
*\end{array}$ \\
\hline $\begin{array}{l}\operatorname{IgG} \\
(\mathrm{g} / 1)\end{array}$ & $\begin{array}{l}0-4 \\
0-12\end{array}$ & $\begin{array}{l}13 \cdot 6 \\
13 \cdot 4\end{array}$ & $\begin{array}{l}2 \cdot 7 \\
2 \cdot 7\end{array}$ & $\begin{array}{l}12 \cdot 3 \\
11.7\end{array}$ & $\begin{array}{l}2 \cdot 6 \\
2 \cdot 1\end{array}$ & $\stackrel{* *}{* * *}$ \\
\hline $\begin{array}{l}\text { ALP } \\
(\mu \mathrm{mol} / \mathrm{s} \text { per } 1)\end{array}$ & $\begin{array}{l}0-4 \\
0-12\end{array}$ & $\begin{array}{l}2 \cdot 7 \\
2 \cdot 7\end{array}$ & $\begin{array}{l}0 \cdot 6 \\
0 \cdot 6\end{array}$ & $\begin{array}{l}3 \cdot 0 \\
4 \cdot 6\end{array}$ & $\begin{array}{l}0.8 \\
1.5\end{array}$ & $\begin{array}{l}\text { NS } \\
* * *\end{array}$ \\
\hline $\begin{array}{l}\text { ASAT } \\
(\mu \mathrm{mol} / \mathrm{s} \text { per l })\end{array}$ & $\begin{array}{l}0-4 \\
0-12\end{array}$ & $\begin{array}{l}0.42 \\
0.42\end{array}$ & $\begin{array}{l}0 \cdot 1 \\
0 \cdot 1\end{array}$ & $\begin{array}{l}0 \cdot 46 \\
0.27\end{array}$ & $\begin{array}{l}0 \cdot 2 \\
0 \cdot 1\end{array}$ & $\begin{array}{l}\text { NS } \\
* * *\end{array}$ \\
\hline $\begin{array}{l}\text { ALAT } \\
(\mu \mathrm{mol} / \mathrm{s} \text { per } \mathrm{l})\end{array}$ & $\begin{array}{l}0-4 \\
0-12\end{array}$ & $\begin{array}{l}0 \cdot 21 \\
0 \cdot 22\end{array}$ & $\begin{array}{l}0 \cdot 1 \\
0 \cdot 1\end{array}$ & $\begin{array}{l}0 \cdot 21 \\
0 \cdot 12\end{array}$ & $\begin{array}{l}0.1 \\
0.04\end{array}$ & $\underset{* * *}{N S}$ \\
\hline
\end{tabular}

ALP, alkaline phosphatase (EC 3.1.3.1); ASAT, aspartate aminotransferase $(E C 2.6 .1,1)$; ALAT, alanine aminotransferase $(E C 2,6,1,2)$.

NS, not significant; $P<0.05, * * P<0.01$, *** $P<0.001$.

\section{DISCUSSION}

It is, of course, impossible to attribute the objective and subjective findings to part or parts of this multifactorial treatment with any degree of specificity. For the time being the regimen must be considered as a whole and the results as an effect of the total treatment. We considered, however, that single factors within the regimen, for example salt abstinence or 
Table 9. Blood values before and after 1 year of vegan therapy in hypertensive patients (Mean values and standard deviations)

\begin{tabular}{|c|c|c|c|c|c|c|}
\hline & \multirow{2}{*}{$\begin{array}{c}\text { Period of } \\
\text { therapy (months) }\end{array}$} & \multicolumn{2}{|c|}{ Before therapy } & \multicolumn{2}{|c|}{ After therapy } & \multirow{2}{*}{$\begin{array}{c}\text { Statistical } \\
\text { significance } \\
\text { of the difference }\end{array}$} \\
\hline & & Mean & SD & Mean & SD & \\
\hline $\mathrm{ESR}(\mathrm{mm})$ & $\begin{array}{l}0-4 \\
0-12\end{array}$ & $\begin{array}{l}15 \\
15\end{array}$ & $\begin{array}{l}10 \cdot 9 \\
10 \cdot 9\end{array}$ & $\begin{array}{l}6 \\
9\end{array}$ & $\begin{array}{l}4 \cdot 4 \\
6 \cdot 8\end{array}$ & $\begin{array}{l}* * * \\
* *\end{array}$ \\
\hline TIBC $(\mu \mathrm{mol} / \mathrm{l})$ & $\begin{array}{l}0-4 \\
0-12\end{array}$ & $\begin{array}{l}59 \cdot 6 \\
59.9\end{array}$ & $\begin{array}{l}7.9 \\
7.5\end{array}$ & $\begin{array}{l}61 \cdot 6 \\
64 \cdot 9\end{array}$ & $\begin{array}{l}6 \cdot 9 \\
6 \cdot 3\end{array}$ & $\underset{* *}{\text { NS }}$ \\
\hline Iron $(\mu \mathrm{mol} / \mathrm{l})$ & $\begin{array}{l}0-4 \\
0-12\end{array}$ & $\begin{array}{l}20 \cdot 8 \\
21 \cdot 3\end{array}$ & $\begin{array}{l}5 \cdot 6 \\
5 \cdot 2\end{array}$ & $\begin{array}{l}16 \cdot 3 \\
18 \cdot 1\end{array}$ & $\begin{array}{l}4 \cdot 8 \\
4 \cdot 4\end{array}$ & $\begin{array}{l}* * \\
\text { NS }\end{array}$ \\
\hline $\begin{array}{l}\text { Leucocytes } \\
\left(10^{*} / 1\right)\end{array}$ & $\begin{array}{l}0-4 \\
0-12\end{array}$ & $\begin{array}{l}6.77 \\
6.77\end{array}$ & $\begin{array}{l}2 \cdot 2 \\
2 \cdot 2\end{array}$ & $\begin{array}{l}4 \cdot 47 \\
4 \cdot 74\end{array}$ & $\begin{array}{l}1 \cdot 1 \\
2 \cdot 0\end{array}$ & $\stackrel{* * *}{*}$ \\
\hline
\end{tabular}

ESR, erythrocyte sedimentation rate; TIBC, total iron-binding capacity. NS, not significant, ${ }^{*} P<0.05, * * P<0.01, * * * P<0.001$.

Table 10. Urine tests before and after 1 year of vegan diet therapy in hypertensive patients

(Mean values and standard deviations)

\begin{tabular}{|c|c|c|c|c|c|c|}
\hline \multirow[b]{2}{*}{ Urine } & \multirow{2}{*}{$\begin{array}{l}\text { Period of } \\
\text { therapy (months) }\end{array}$} & \multicolumn{2}{|c|}{ Before therapy } & \multicolumn{2}{|c|}{ After therapy } & \multirow{2}{*}{$\begin{array}{c}\text { Statistical } \\
\text { significance } \\
\text { of the difference }\end{array}$} \\
\hline & & Mean & SD & Mean & SD & \\
\hline $\begin{array}{l}\text { Osmolality } \\
(\operatorname{mosm} / 1)\end{array}$ & $\begin{array}{l}0-4 \\
0-12\end{array}$ & $\begin{array}{l}292 \\
297\end{array}$ & $\begin{array}{l}150 \cdot 1 \\
154 \cdot 7\end{array}$ & $\begin{array}{l}201 \\
359\end{array}$ & $\begin{array}{l}130 \cdot 4 \\
143 \cdot 3\end{array}$ & $\begin{array}{l}* * * \\
\text { NS }\end{array}$ \\
\hline $\begin{array}{l}\text { Chloride } \\
\text { (mmol/l) }\end{array}$ & $\begin{array}{l}0-4 \\
0-12\end{array}$ & $\begin{array}{l}46 \\
45\end{array}$ & $\begin{array}{l}34.9 \\
35 \cdot 0\end{array}$ & $\begin{array}{l}21 \\
67\end{array}$ & $\begin{array}{l}16 \cdot 3 \\
31 \cdot 3\end{array}$ & $\stackrel{* *}{*}$ \\
\hline $\begin{array}{l}\text { Chloride } \\
\text { (mmol/24 h) }\end{array}$ & $\begin{array}{l}0-4 \\
0-12\end{array}$ & $\begin{array}{l}92 \\
89\end{array}$ & $\begin{array}{l}60 \cdot 3 \\
54 \cdot 9\end{array}$ & $\begin{array}{l}36 \\
97\end{array}$ & $\begin{array}{l}23 \cdot 7 \\
56 \cdot 7\end{array}$ & $\begin{array}{l}* * * \\
\text { NS }\end{array}$ \\
\hline
\end{tabular}

NS, not significant; ${ }^{*} P<0.05,{ }^{* *} P<0.01,{ }^{* * *} P<0.001$.

weight loss, were not enough to explain the results obtained. Some patients had previously tried such single factors without success. Since the decrease in salt intake could be indicated by urine chloride at 4 months but not at 1 year, it seems that the effect which remained at 1 year cannot be ascribed entirely to the reduced salt intake. Since the decrease in blood pressure was less at 1 year than at 4 months, it is perhaps possible that the inability of the patients to maintain this low salt intake can be seen as an indication of the importance of salt restriction.

The patients did not, quite understandably, adhere fully to the prescribed regimen. Even strict vegetarians do not follow all the rules and restrictions during their entire life (Roth, 1976). A compliance, which on average was estimated at $84 \%$, must be considered as a favourable result since many patients were discouraged by friends, family and doctors.

The decrease in blood pressure was not great. It must, however, be seen in context considering the fact that during the treatment the patients stopped most antihypertensive medication, which was intended to keep their blood pressure low. It would seem, therefore, that the regimen was able to replace this medication. 


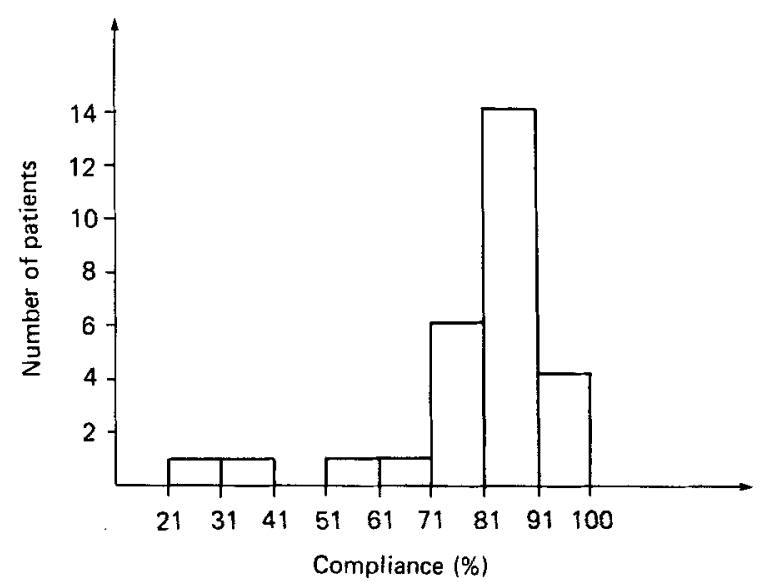

Fig. 3. The patients' compliance to the food regimen according to their subjective evaluation. Mean $84 \%$.

Kempner's (1948) rice diet is an example of a diet for hypertension. However, this has been abandoned as a therapy because it is too monotonous. Stamler et al. (1980) also showed a positive effect of diet therapy for moderate hypertension. It may be that the vegan food regimen is difficult for many people to maintain. Probably not all patients suffering from hypertension would accept this treatment. Patients who, for various reasons, are interested in 'food therapy' and who can adjust themselves to this regimen, seem to have benefited from it as an alternative to conventional medication.

The study reported here was supported in part by grants-in-aid from the Research Foundation of the Swedish Ministry for Social Affairs, Svenska Journalen, Hälsokostrådet, Sweden.

\section{REFERENCES}

Abdulla, M., Andersson, I., Asp, N-G., Berthelsen, K., Birkhed, D., Dencker, I., Johansson, C-G., Jägerstad, M., Kolar, K., Nair, B. M., Nilsson-Ehle, P., Nordén, A., Rassner, S., Åkesson, B. \& Öckerman, P-A. (1981). American Journal of Clinical Nutrition 34, 2464-2474.

Black, H. R. (1979). American Journal of Medicine 66, 837.849.

Chiang, B. N., Perlman, L. V. \& Epstein, F. H. (1969). Circulation 41, 403-410.

Freis, E. D. (1976). Circulation 53, 589-596.

Haddy, F. J. (1980). American Journal of Medicine 69, 746-757.

Kempner, W. (1948). American Journal of Medicine 4, 545-561.

Kempner, W. (1949). Annals of Internal Medicine 31, 821-856.

Lindahl, O. \& Lindwall, L. (1978). Vetenskap och beprövad erfarenhet. Stockholm: Natur \& Kultur.

Mann, G. V. (1974). New England Journal of Medicine 274, 178-226.

Roth, J. A. (1976). Health Purifiers and Their Enemies. New York: Prodist.

Stamler, J. (1980). Journal of the American Medical Association 243, 1819-1823. 